\title{
Tuning the Properties of Penetrating Peptides by Oxime Conjuga- tion
}

\author{
Marta Pazo \\ Héctor Fernández-Caro \\ Juan M. Priegue \\ Irene Lostalé-Seijo \\ Javier Montenegro*
}

Singular Research Centre in Chemical Biology and Molecula Materials, (CIQUS), Organic Chemistry Department, University of Santiago de Compostela (USC), Santiago de Compostela, Spain

javier.montenegro@usc.es

Published as part of the Special Section $8^{\text {th }}$ EuCheMs Organic Division Young Investigators Workshop

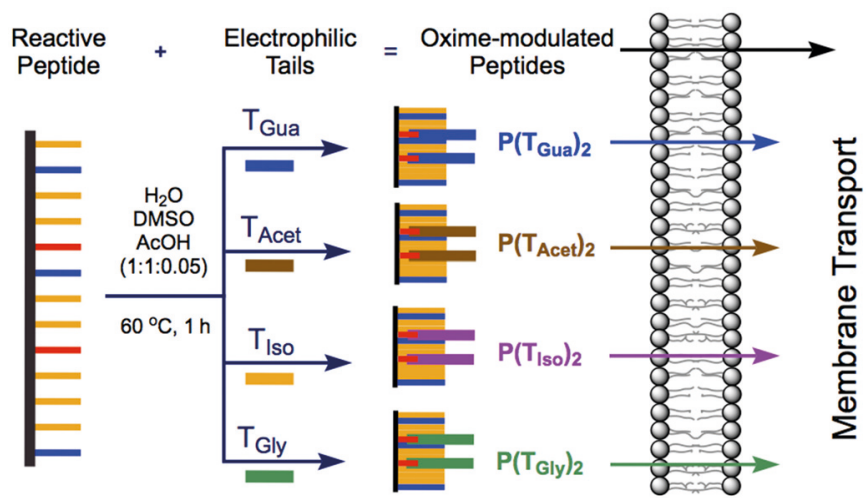

tionally, the conformational changes of the transported peptides are difficult to discern and to study in real time. ${ }^{16,17}$ However, it has been recently shown that the cationic arginine topology dramatically influences important steps of the delivery process including endosomal escape. ${ }^{18}$

The formation of dynamic bonds constitutes a powerful strategy for the preparation of amphiphilic membrane transporters. ${ }^{14,19-23}$ Dynamic bonds such as hydrazones, oximes and disulfides offer two fundamental advantages for the synthesis of membrane carriers. ${ }^{24-28}$ First, there is a synthetic advantage, because certain dynamic bonds (i.e. hydrazone, oxime, disulfide) can be considered as 'clickable chemistry' as they lead to the final products in short times, with high yields and without side products. On the other hand, dynamic bonds are sensitive to external stimuli and therefore they can readapt to changes in the environment along the internalization pathway.

We have recently started a research program aimed to decipher the critical structure-activity relationships of penetrating peptides. This approach is based in the implementation of dynamic chemical bonds to change (modulate) the structures and thus the activity of initial model peptide sequences. In this paper we report proof of concept transport experiments, in vesicles and in cells, of an amphiphilic pseudo-helical short peptide that is functionalized by oxime bond formation with hydrophilic and hydrophobic electrophilic counterparts.

This parent peptide named $\mathrm{AcP}(\mathrm{Ox})_{2}$ (Figure $1 \mathrm{~A}$ ), where Ac stands for acetyl N-terminal, $\mathrm{P}$ for peptide backbone and Ox for the two alkoxyamine pendants, was synthesized by solid-phase peptide synthesis using orthogonal protecting groups (Figure S1). ${ }^{21}$ Lysine amino acids with the lateral protecting group methyltrytil (Mtt) were employed in or- 


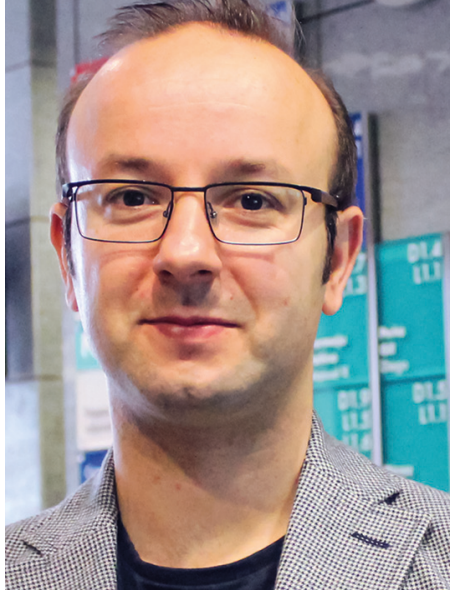

Javier Montenegro received his PhD (2009) from the University of Santiago de Compostela (USC, Prof. Susana López). In 2005 he was a visiting scientist in the group of Prof. Steven Ley (Cambridge University) and in 2007 he was a visiting scientist with Prof. Reza M. Ghadiri (Scripps). In 2009 he moved to the University of Geneva for three years of postdoctoral studies with Prof. Stefan Matile. In 2012 he obtained a Juan de la Cierva fellowship (Prof. Juan R. Granja) and in 2014 a Ramon y Cajal contract at the Organic Chemistry Department and the CIQUS at the USC. In 2015 he was awarded with a Starting Grant from the European Research Council (ERC). His research interests lay at the interphase between organic synthetic and supramolecular chemistry applied to biological systems and the discovery of new materials. His current projects are focused in the topological control of supramolecular assemblies for broad applications such as differential sensing, controlled delivery and tubular-templated composites.

der to perform the selective deprotection and the 'on resin' coupling of the Boc-protected alkoxyamine pendants (Figure S1). The peptide was terminated by acetylation, fully deprotected, purified by reverse-phase HPLC and characterized by different spectroscopic techniques (see Supporting Information). The sequence of $\mathrm{AcP}(\mathrm{Ox})_{2}$ was chosen to give rise to an helical peptide with a similar number of cationic and hydrophobic functionalities after oxime bond formation with a guanidinium aldehyde (Figure 1B). In this peptide, the alkoxyamine nucleophilic moieties are located at the interphase between the hydrophilic and the hydrophobic domains in order to minimize the impact over the secondary structure. The circular dichroism analysis, in water and in trifluoroethanol (TFE), showed bands at 208 and 222 $\mathrm{nm}$, respectively, indicating a certain helical behavior of this parent peptide $\operatorname{AcP}(\mathrm{Ox})_{2}$. Although helical character decreased in aqueous conditions, it was retained at high temperatures (Figure 1B).

$\mathrm{AcP}(\mathrm{Ox})_{2}$ is ready to react with aldehydes $\left(\mathrm{H}_{2} \mathrm{O} / \mathrm{DMSO} / \mathrm{AcOH}\right.$ $1: 1: 0.05,60{ }^{\circ} \mathrm{C}, 1 \mathrm{~h}$ ) to afford the corresponding oximemodulated peptides that can be readily used in transport experiments under physiological conditions and without any further purification (Figure 1C, see Supporting Information for details).

We carried out initial transport experiments in model membranes to screen the transport ability of this peptide with a short double stranded nucleotide cargo (herring DNA, $<50$ base pairs). For this purpose we prepared egg yolk phosphatidylcholine (EYPC) large unilamellar vesicles (LUVs) loaded with the anionic fluorophore 8-hydroxy1,3,6-pyrenetrisulfonate (HPTS) and the cationic quencher $p$-xylene-bispyridinium bromide (DPX) (Figure 2). ${ }^{23,24}$ In this assay, the intravesicular concentrations of dye (HPTS) and quencher (DPX) are balanced to afford minimal emission of the resting state vesicles (see Supporting Informa-
A)
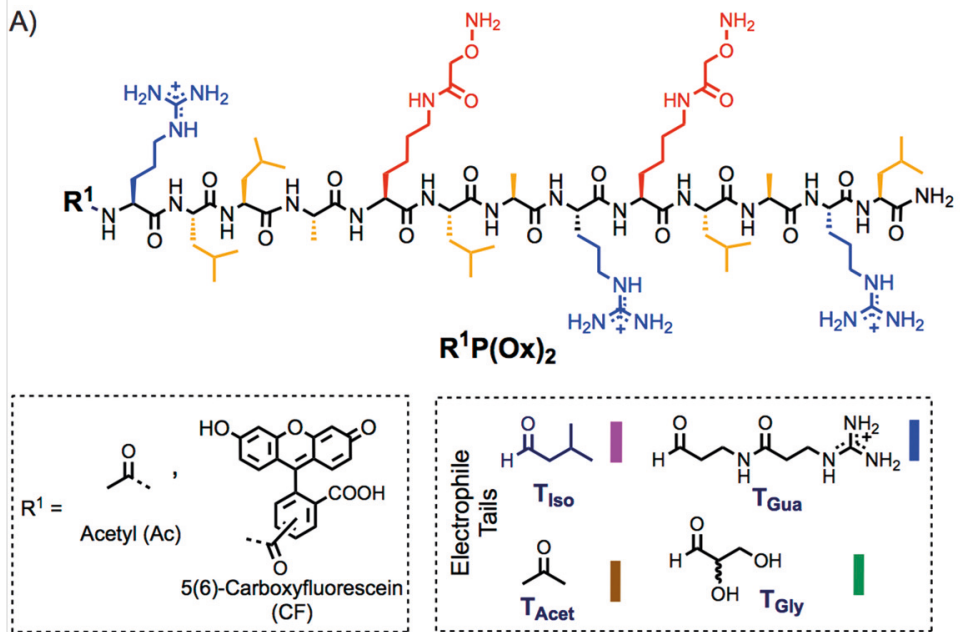

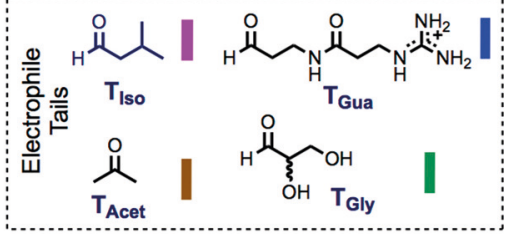

B)
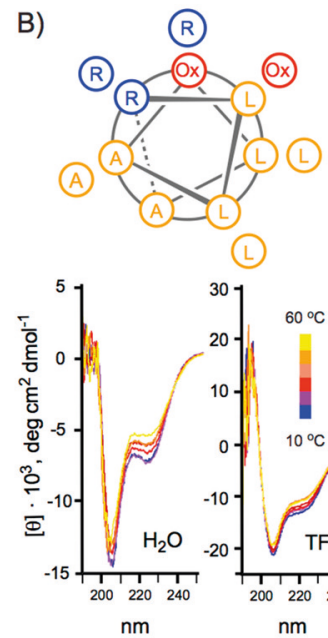

Figure 1 (A) Structure of the peptide $R_{1} P(O x)_{2}$. Arginine residues are in blue, leucines and alanines in orange and reactive alkoxyamines in red. Different electrophilic aldehyde tails employed: $\mathrm{T}_{\text {Iso }}$ (isovaleraldehyde), $\mathrm{T}_{\text {Acet }}$ (acetone), $\mathrm{T}_{\text {Gly }}$ (glyceraldehyde), $\mathrm{T}_{\text {Gua }}$ (guanidinium aldehyde). (B) Top-view helical diagram (heptad) and circular dichroism spectra at different temperatures $\left(10-60{ }^{\circ} \mathrm{C}\right)$ of the parent peptide $\mathrm{AcP}(\mathrm{Ox})_{2}$. $(\mathrm{C})$ Acronym definition and scheme for peptide functionalization with the different aldehydes to afford oxime-modulated peptides for membrane transport applications. Color code: black: peptide backbone; blue: arginine; orange: leucine; red: reactive alkylhydroxylamine; purple: isovaleraldehyde; green: glyceraldehyde; brown: acetone. 
tion). In the transport experiment, we measured the emission of the HPTS of vesicles suspensions upon sequential addition of the different components (peptide, DNA and detergent; Figure 2). The first addition of the peptide alone (at $t=25 \mathrm{~s}$ ) should not lead to any increase in the fluorescence unless the cationic peptide behaves as a mere detergent. However, if the following second addition of the anionic DNA (at $t=50 \mathrm{~s}$ ) leads to an increase in the fluorescence emission, the peptide behaves as an activator of the DNA membrane translocation (Figure 2). At the end of the experiment $(t=225 \mathrm{~s})$ we added a potent detergent (Triton-X$100)$ to release all the vesicle contents and normalize the data.
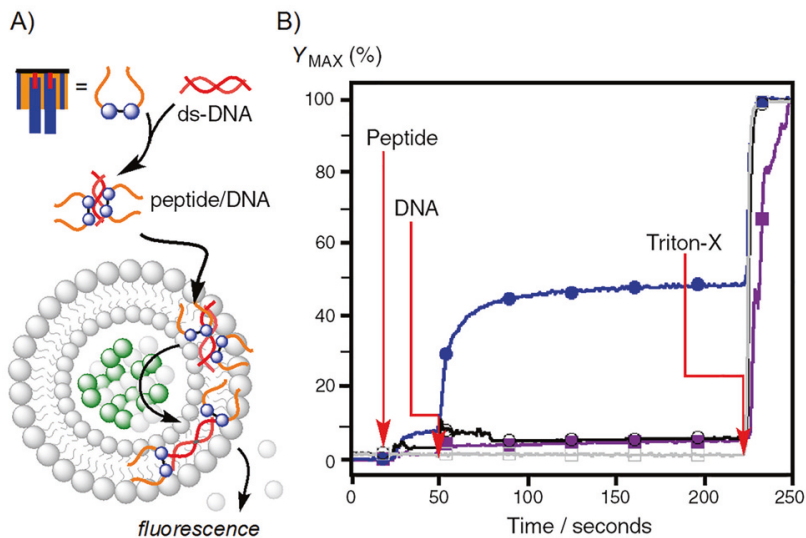

Figure 2 Vesicle transport experiments. (A) Scheme of the vesicle transport experiments. (B) Representative normalized kinetics of transporter-mediated increase in HPTS fluorescence, following addition of peptide $(5 \mathrm{nM}, t=25 \mathrm{~s})$, DNA (herring DNA, $<50 \mathrm{bp}, 700 \mathrm{nM}, t=50 \mathrm{~s}$ ) and Triton-X-100 (7.5 $\mu \mathrm{M}, t=225 \mathrm{~s})$. Kinetic traces demonstrating increasing transporter activity for $\mathrm{AcP}\left(\mathrm{T}_{\mathrm{Gua}}\right)_{2}$ (filled blue circles), lack of activity for the $\operatorname{AcP}\left(\mathrm{T}_{\mathrm{Iso}}\right)_{2}$ (filled purple squares), control experiment with parent peptide $\mathrm{AcP}(\mathrm{Ox})_{2}$ (empty black circles) and control experiment with only vesicles (empty gray squares).

Two different aldehydes (hydrophilic and hydrophobic) were selected to test oxime-modulated transport in vesicles, namely $\mathrm{T}_{\text {Gua }}$ (guanidinium aldehyde) and $\mathrm{T}_{\text {Iso }}$ (isovaleraldehyde; Figures S3 and S4). The normalized transport kinetics showed that the parent peptide $\operatorname{AcP}(\mathrm{Ox})_{2}$ was totally inactive (Figure 2B). However, an important increase in the activity was observed after the oxime linkage of the peptide with the cationic hydrophilic aldehyde $\mathrm{T}_{\mathrm{Gua}}$ (Figure $2 \mathrm{~B}$ ). Increasing the hydrophobic character of the parent peptide with the leucine mimic $\mathrm{T}_{\text {Iso }}$ did not increase the transport activity. This result is in clear contrast with previous observations of dendritic hydrazone and oxime-based amphiphiles, ${ }^{24,29-31}$ which required a strong hydrophobic enrichment in order to activate DNA transport across the lipid bilayer of LUVs.

To further investigate and visualize oxime-modulated peptides in cells, the peptide was terminated with a carboxyfluorescein $(\mathrm{CF})$ fluorescent probe (Figure 1A, Figure
S5). After fluorophore attachment, the labelled parent peptide was not completely stable so it was directly reacted with three different electrophile modulators, namely glyceraldehyde $\left(\mathrm{T}_{\mathrm{Gly}}\right.$, neutral hydrophilic, Figure $\left.\mathrm{S} 6\right)$, guanidinium aldehyde $\left(\mathrm{T}_{\mathrm{Gua}}\right.$, cationic hydrophilic, Figure $\mathrm{S7}$ ) and acetone $\left(\mathrm{T}_{\text {Acet }}\right.$, hydrophobic, Figure $\left.\mathrm{S} 8\right)$.

After reaction with the aldehydes the three stable oxime-bonded peptides were incubated with HeLa cells and the uptake was quantified after cell washings and trypsinization to remove the excess of the membrane-bound peptides (Figure 3A, see Supporting Information). Interestingly, the three peptides $\left[\mathrm{CFP}\left(\mathrm{T}_{\mathrm{Gly}}\right)_{2}, \mathrm{CFP}\left(\mathrm{T}_{\text {Acet }}\right)_{2}, \mathrm{CFP}\left(\mathrm{T}_{\mathrm{Gua}}\right)_{2}\right]$ showed higher levels of internalization than the prototypical octaarginine penetrating peptide $\mathrm{CFR}_{8}$ (Figure $3 \mathrm{~A}$ ). Intriguingly, the incorporation of the cationic $\mathrm{T}_{\mathrm{Gua}}$ lead to the highest level of internal fluorescence, which was in good agreement with the DNA transport experiments in vesicles.

Cell viability in the presence of the three oxime peptides was studied by following the colorimetric 2,5-diphenyltetrazolium bromide reduction to formazan (MTT assay, see Supporting Information). Interestingly, this assay confirmed that cationic enhancement did not only improve the uptake but also the cellular viability (Figure 3B). The peptide modified by oxime bond formation with acetone induced a reduction of cell viability probably due to membrane disruption of the more hydrophobic peptide (Figure 3B).

The three peptides were also studied using inverted epifluorescence microscopy after incubation at $4 \mu \mathrm{M}$ with HeLa cells (Figure 3C). The pictures confirmed a different behavior of the three peptides in cells (Figure 3C). The octaarginine control peptide $\left(\mathrm{CFR}_{8}\right)$ showed the typical combination of cytoplasm distribution together with tiny punctate fluorescence, indicating membrane translocation and energy-dependent endocytosis (Figure 3C). ${ }^{10}$ The peptide modified with the neutral glyceraldehyde, $\operatorname{CFP}\left(\mathrm{T}_{\mathrm{Gly}}\right)_{2}$, showed a higher level of bigger internal aggregates suggesting an increase in the size of the transported particles. The peptide capped with acetone, $\operatorname{CFP}\left(\mathrm{T}_{\text {Acet }}\right)_{2}$, showed a diffuse cytoplasmic distribution. A similar behavior, but to a greater extent, was observed for the amphiphilic peptide modified with the cationic aldehyde $\left[\mathrm{CFP}\left(\mathrm{T}_{\mathrm{Gua}}\right)_{2}\right]$. The clear enhancement of transport efficiency in vesicles and in cells confirmed that the guanidinium derivative $\mathrm{R}_{1} \mathrm{P}\left(\mathrm{T}_{\mathrm{Gua}}\right)_{2}$ was the leader of this small series.

To get further insight into the internalization mechanism and confirm the endosomal pathway, we performed microscopy experiments in HeLa cells in the presence of LysoTracker Deep Red (Figure 4). These experiments confirmed that the punctate fluorescence was due to the presence of endosomes for the octa-arginine $\left(\mathrm{CFR}_{8}\right)$ and the glyceraldehyde oxime peptide $\left[\mathrm{CFP}\left(\mathrm{T}_{\mathrm{Gly}}\right)_{2}\right.$; Figure 4]. The membrane transport properties of penetrating peptides are highly dependent on the concentration of the cellular incubation experiment. ${ }^{1,4}$ Therefore, to avoid signal saturation and to check for the potential endocytosis of the highly ac- 
A)

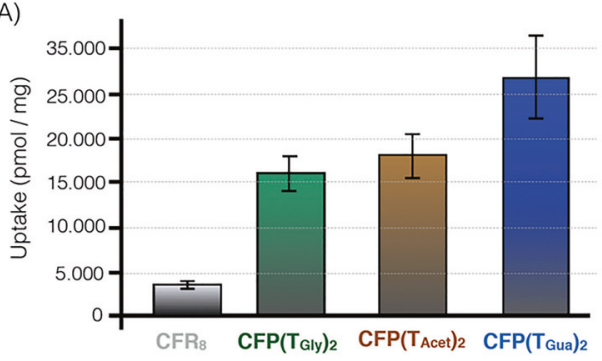

B)

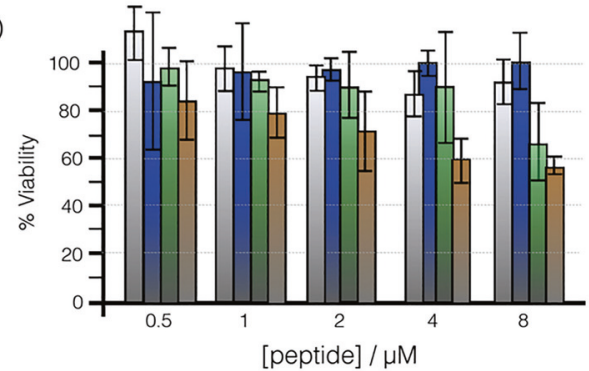

C)
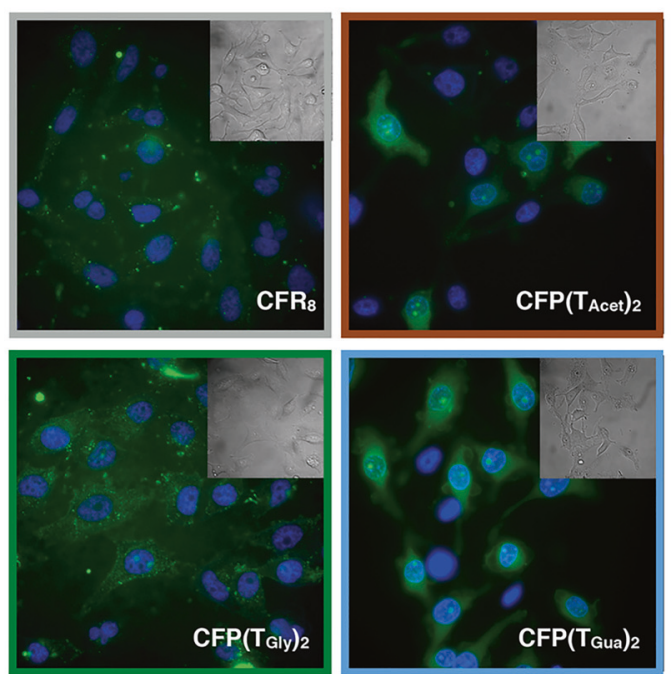

Figure 3 Cell transport experiments of the three oxime-modulated peptides CFP(T) 2 and the control CFR . (A) Quantification of the uptake of the peptides by fluorometry. HeLa cells were incubated for 30 min with the indicated fluorescein labeled peptides (4 $\mu \mathrm{M})$ in HKR buffer. Cells were then washed and trypsinized and the cellular uptake was quantified by fluorometry. (B) Cell viability (MTT assay). Error bars indicate SD of three replicates.

tive peptides bonded with acetone and guanidinium aldehydes we carried out a one half dilution of the initial concentrations. We observed that $\left[\mathrm{CFP}\left(\mathrm{T}_{\mathrm{Gua}}\right)_{2}\right]$ showed a very similar pattern as the $\mathrm{CFR}_{8}$ and the fluorescence image, in the presence of LysoTracker, showed cytoplasm distribution together with co-localization in the lysosomes (Figure 4). The peptide capped with acetone did not show the similar co-localization, an observation that could be related to the membrane lytic properties and a potential endosomal disruption of the more hydrophobic $\operatorname{CFP}\left(\mathrm{T}_{\text {Acet }}\right)_{2}$.

Increasing cationic and hydrophobic character of penetrating peptides can lead to toxic undesired effects. ${ }^{1}$ However, in the particular example reported here, increasing the cationic character by introducing more guanidinium aldehydes in a parent amphiphilic peptide strongly increased the cellular uptake (Figure 3B). This increase in uptake ob- served for the peptide [CFP( $\left.\mathrm{T}_{\mathrm{Gua}}\right)_{2}$ ] could suggest the importance of the hydrophobicity of the leucine moieties that would enhance the membrane partition and the penetrating properties of any given peptide.

These results confirmed the important consequences in the transport activity after covalent/dynamic modification of an initial parent penetrating peptide scaffold. Although much more data will be required to validate this trend, the results reported here suggest that the hydrophilicity/hydrophobicity ratio could be an important factor to consider with implications in the supramolecular properties and in the transport capabilities of any given peptide. These implications would not only be limited to the level of delivery efficiency but also to the final mechanism of internalization. With this paper we wanted to highlight the potential of dynamic bonds as powerful synthetic tools to modulate the
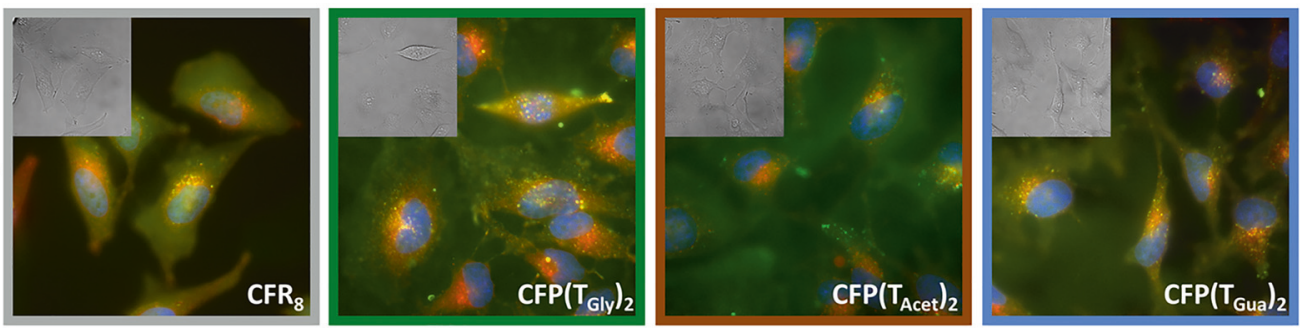

Figure 4 Lysosomal staining of cells incubated with the peptides. After three hours of incubation with the fluorescein-labelled peptides (green), cells were stained with LysoTracker Deep Red (red). Nuclei were counterstained with Hoechst (blue). Some co-localization between the lysosomal marker and the four peptides is observed with particular high intensity for the case of $\operatorname{CFP}\left(\mathrm{T}_{\mathrm{Gly}}\right)_{2}$ and $\mathrm{CFR}_{8}$ at $4 \mu \mathrm{M}$. For the high penetrating $\operatorname{CFP}\left(\mathrm{T}_{\mathrm{Acet}}\right)_{2}$ and $\operatorname{CFP}\left(\mathrm{T}_{\mathrm{Gua}}\right)_{2}$ it was necessary to dilute the concentration to $2 \mu \mathrm{M}$ to avoid signal saturation and observe the colocalization. 
activity of penetrating peptides. In this article we have focused on the synthetic advantage of the oxime bonds. However, in the future, we hope that also the dynamic character and the response to external stimuli of dynamic covalent chemistry will allow us to understand cell penetration and to develop novel and superior intracellular delivery vehicles.

\section{Acknowledgment}

This work was supported by the Spanish Ministry of Economy and Competitivity (MINECO) [CTQ2014-59646-R], the Xunta de Galicia (ED431G/09) and the ERDF. J.P. received an F.P.I. fellowship from MINECO. J.M. received a Ramon y Cajal (RYC-2013-13784) and an ERC Starting Investigator Grant (DYNAP-677786).

\section{Supporting Information}

Supporting information for this article is available online at https://doi.org/10.1055/s-0036-1588689.

\section{References}

(1) Fischer, P. M. Med. Res. Rev. 2007, 27, 755.

(2) Duchardt, F.; Fotin-Mleczek, M.; Schwarz, H.; Fischer, R.; Brock, R. Traffic 2007, 8, 848.

(3) Stewart, K. M.; Horton, K. L.; Kelley, S. O. Org. Biomol. Chem. 2008, 6, 2242.

(4) Langel, Ü. Cell-Penetrating Peptides: Methods and Protocols; Humana Press Inc.: Totowa, NJ, 2011.

(5) Koren, E.; Torchilin, V. P. Trends Mol. Med. 2012, 18, 386.

(6) Kauffman, W. B.; Fuselier, T.; He, J.; Wimley, W. C. Trends Biochem. Sci. 2015, 40, 749.

(7) Stanzl, E. G.; Trantow, B. M.; Vargas, J. R.; Wender, P. A. Acc. Chem. Res. 2013, 46, 2944.

(8) Blum, A. P.; Kammeyer, J. K.; Gianneschi, N. C. Chem. Sci. 2016, 7, 989.

(9) Bai, Y.; Nguyen, L.; Song, Z.; Peng, S.; Lee, J.; Zheng, N.; Kapoor, I.; Hagler, L. D.; Cai, K.; Cheng, J.; Chan, H. Y. E.; Zimmerman, S. C. J. Am. Chem. Soc. 2016, 138, 9498.
(10) Madani, F.; Lindberg, S.; Langel, Ü.; Futaki, S.; Gräslund, A. J. Biophys. 2011, 2011, 1 .

(11) Richard, J. P.; Melikov, K.; Vives, E.; Ramos, C.; Verbeure, B.; Gait, M. J.; Chernomordik, L. V.; Lebleu, B. J. Biol. Chem. 2003, 278, 585.

(12) Nakase, I.; Takeuchi, T.; Tanaka, G.; Futaki, S. Adv. Drug. Deliv. Rev. 2008, 60, 598.

(13) Herce, H. D.; Garcia, A. E.; Cardoso, M. C. J. Am. Chem. Soc. 2014 $136,17459$.

(14) Gasparini, G.; Bang, E.-K.; Montenegro, J.; Matile, S. Chem. Commun. 2015, 51, 10389.

(15) Hansen, M.; Kilk, K.; Langel, Ü. Adv. Drug. Deliv. Rev. 2008, 60, 572 .

(16) Magzoub, M.; Eriksson, L. E. G.; Gräslund, A. Biochim. Biophys. Acta 2002, 1563, 53.

(17) Eiríksdóttir, E.; Konate, K.; Langel, Ü.; Divita, G.; Deshayes, S. Biochim. Biophys. Acta 2010, 1798, 1119.

(18) Appelbaum, J. S.; La Rochelle, J. R.; Smith, B. A.; Balkin, D. M.; Holub, J. M.; Schepartz, A. Chem. Biol. 2012, 19, 819.

(19) Montenegro, J.; Matile, S. Chem. Asian J. 2010, 6, 681.

(20) Gehin, C.; Montenegro, J.; Bang, E.-K.; Cajaraville, A.; Takayama, S.; Hirose, H.; Futaki, S.; Matile, S.; Riezman, H.J. Am. Chem. Soc. 2013, 135, 9295.

(21) Priegue, J. M.; Montenegro, J.; Granja, J. R. Small 2014, 10, 3613.

(22) Gasparini, G.; Sargsyan, G.; Bang, E.-K.; Sakai, N.; Matile, S. Angew. Chem. 2015, 127, 7436.

(23) Priegue, J. M.; Crisan, D. N.; Martínez-Costas, J.; Granja, J. R.; Fernandez-Trillo, F.; Montenegro, J. Angew. Chem. Int. Ed. 2016, $55,7492$.

(24) Montenegro, J.; Bang, E.-K.; Sakai, N.; Matile, S. Chem. Eur. J. 2012, 18, 10436.

(25) Bode, S. A.; Wallbrecher, R.; Brock, R.; van Hest, J. C. M.; Löwik, D. W. P. M. Chem. Commun. 2013, 50, 415.

(26) Mahon, C. S.; Fulton, D. A. Chem. Sci. 2013, 4, 3661.

(27) Bartolami, E.; Bessin, Y.; Gervais, V.; Dumy, P.; Ulrich, S. Angew. Chem. Int. Ed. 2015, 54, 10183

(28) Bartolami, E.; Bessin, Y.; Bettache, N.; Gary-Bobo, M.; Garcia, M.; Dumy, P.; Ulrich, S. Org. Biomol. Chem. 2015, 13, 9427.

(29) Takeuchi, T.; Montenegro, J.; Hennig, A.; Matile, S. Chem. Sci. 2011, 2, 303.

(30) Montenegro, J.; Fin, A.; Matile, S. Org. Biomol. Chem. 2011, 9, 2641.

(31) Montenegro, J.; Braun, J.; Fischer-Onaca, O.; Meier, W.; Matile, S. Org. Biomol. Chem. 2011, 9, 6623. 